\title{
Serum selenium determinants in French adults: the SU.VI.M.AX study
}

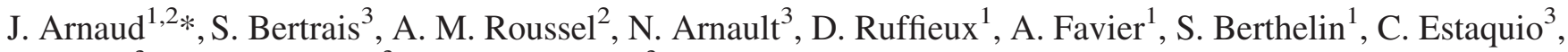 \\ P. Galan ${ }^{3}$, S. Czernichow ${ }^{3}$ and S. Hercberg ${ }^{3}$ \\ ${ }^{1}$ Département de Biologie Intégrée, CHU de Grenoble, BP 217, 38043 Grenoble cedex 9, France \\ ${ }^{2}$ Nutrition, Vieillissement et Maladies Cardiovasculaires, Faculté de Pharmacie, Université Joseph Fourier, Domaine de la Merci, \\ 38700 La Tronche, France \\ ${ }^{3}$ U557 Inserm (UMR Inserm-Inra-Cnam), Institut Scientifique et Technique de la Nutrition et de l'Alimentation, 5 rue Vertbois, \\ 75003 Paris, France
}

(Received 15 February 2005 - Revised 19 May 2005 - Accepted 19 May 2005)

\begin{abstract}
The objective of the present work was to assess the relationship between serum Se concentrations and environmental determinants (i.e. lifestyle, social activity, geographic region, urban status, education, familial status, physical activity, BMI, tobacco, and food and alcohol consumption). Baseline results from 13017 subjects (7876 women aged 35-60 and 5141 men aged 45-60) who participated in the SU.VI.M.AX (Supplémentation en Vitamines et Minéraux Antioxydants) study were analysed. Fewer than $2 \%$ of the volunteers had a serum Se status under 0.75 $\mu$ mol/l, which has been quoted as the cut-off of biological Se sub-deficiency. Women had significantly lower serum Se concentrations than men (1.09 (SD $0 \cdot 19) \mu \mathrm{mol} / 1$ ( $n$ 7423) and 1.14 (SD 0.20) $\mu \mathrm{mol} / \mathrm{l}(n$ 4915), $P<0 \cdot 0001$, respectively). Significant differences in serum Se concentrations were observed between geographic areas. In both sexes, the serum Se concentration increased with alcohol, meat and fish consumption, and decreased with smoking. In premenopausal women, the serum Se concentration was higher in contraceptive-pill users than in non-users. In women only, age was associated with increased serum Se concentrations, and obesity (BMI $\geq 30 \mathrm{~kg} / \mathrm{m}^{2}$ ) was associated with decreased serum Se levels. In men, we observed a decrease in serum Se concentrations with increased consumption of vegetables and fruits. In conclusion, though few of the volunteers participating in the SU.VI.M.AX study had Se status in the sub-deficiency range, $83 \%$ of women and $75 \%$ of men had serum concentrations below the value considered optimal for glutathione peroxidase activity. The largest Se associations in both sexes were found with regions, smoking, alcohol, meat and fish consumption. Further studies are needed to understand the difference in Se status between genders.
\end{abstract}

Selenium in serum: Selenium determinants: Human nutrition: Lifestyle

The SU.VI.M.AX (Supplémentation en Vitamines et Minéraux Antioxydants) study was a French large-scale longitudinal intervention trial performed in order to evaluate the efficacy of a daily combination of micronutrient antioxidants (vitamins $\mathrm{C}$ and $\mathrm{E}, \beta$-carotene, $\mathrm{Zn}$ and $\mathrm{Se}$ ), at non-pharmacological doses, in reducing the incidence of cancers and cardiovascular diseases. After 7.5 years of follow-up, results from this randomized, double-blind, placebo-controlled, primary-prevention trial showed that combined antioxidant supplementation decreased the risk of cancer in men, and this protective effect was greater among those with low baseline concentrations of serum vitamin $\mathrm{C}$ or vitamin $\mathrm{E}$ (Hercberg et al. 2004). This stimulated interest in identifying factors able to modulate the level of blood antioxidant markers.

Serum Se is considered to be a good index of Se status (Nève, 1991), though previous investigations of determinants of Se status yielded conflicting results (Robberecht \& Deelstra, 1994; Alfthan \& Nève, 1996). The present cross-sectional study focused on socio-demographic, lifestyle and dietary factors related to serum Se concentrations in participants in the SU.VI.M.AX study at baseline.

\section{Materials and methods}

\section{Subjects}

The design of the SU.VI.M.AX study and the characteristics of the participants at baseline have been previously described (Hercberg et al. 1998, 2004). Briefly, 13017 subjects (5141 men aged 40-60 years and 7876 women aged $35-60$ years) were recruited between October 1994 and May 1995 with a planned follow-up of 8 years. These subjects were recruited after a 5-month national multimedia campaign (March to July 1994). At enrolment, all participants supplied details of their past medical history as well as anthropometric, demographic and lifestyle data, and declared themselves to be free of any severe pathologies. Baseline characteristics showed that this cohort was close to the national population in terms of geographic density and socio-economic status (Hercberg et al. 1998). 
All subjects gave their informed written consent to the study. The protocol was approved by a medical ethics committee (CCPPRB no. 706 Paris-Cochin Hospital, France) and the national committee for the protection of privacy and civil liberties (CNIL no. 334641).

\section{Socio-demographic and lifestyle data}

Socio-demographic and lifestyle data were obtained from a questionnaire at baseline. Six categories of age were defined: $<40$ years, 40 to $<45$ years, 45 to $<50$ years, 50 to $<55$ years, 55 to $<60$ years and $\geq 60$ years, with the first one including only women. Family status was categorized as one of two categories (couple life or not). Educational level was coded as three categories according to the highest degree obtained (primary school, high school, university or equivalent). Occupation was separated into three categories (workers, unemployed and retired). France was divided into eleven geographic regions (Alps, Brittany, Burgundy, Centre, Loire lands, Mediterranean coast, Normandy, North, Northeast, Paris outskirts, Southwest). The place of residence was defined by the zip code of each subject at baseline. Four categories were defined according to the definition of the Institut National de la Statistique et des Etudes Economiques (I.N.S.E.E., Paris, France) based on the economic activity of the area corresponding to each subject's zip code (Le Jeannic \& Vidalenc, 1997): urban municipalities provided at least 5000 jobs; suburbs were defined as municipalities surrounding an urban pole; mixed municipalities were those located outside an urban area, but where at least $40 \%$ of the resident population worked in an urban area; and rural municipalities consisted of all other zip codes or municipalities. Five categories of smoking habits were defined: never smokers, former smokers, light current smokers if less than ten cigarettes per day, heavy current smokers if more than twenty cigarettes per day and moderate current smokers if the number of cigarettes smoked per day varied from ten to twenty. Alcohol consumption was divided into three categories: non-drinkers, moderate and heavy drinkers. The cutoff between these two groups was defined at $15 \mathrm{~g} / \mathrm{d}$ for women and $20 \mathrm{~g} / \mathrm{d}$ for men, taking into account the gender differences in alcohol metabolism and in alcohol consumption associated with increased medical risk (Bradley et al. 1998; de Lorimier, 2000; Hines \& Rimm, 2001). Among the drinkers, two categories were defined taking into account red wine consumption (yes or no). BMI was divided into three categories $\left(<25 \mathrm{~kg} / \mathrm{m}^{2}, 25-<30 \mathrm{~kg} / \mathrm{m}^{2}, \geq 30 \mathrm{~kg} / \mathrm{m}^{2}\right)$. Physical activity was also divided into three categories (irregular physical activity; $<1 \mathrm{~h}$ of walking per day, $\geq 1 \mathrm{~h}$ of walking per day). Menopausal status was assessed by a specific questionnaire. In premenopausal women, four categories of contraceptive use were defined (no contraceptive method, contraceptivepills, intrauterine device, other contraceptive methods). In postmenopausal women, two categories were defined based on current use of hormone replacement therapy (yes or no).

\section{Dietary assessment}

Data on dietary intake were available for a subsample of 6390 subjects who agreed to report at least six $24 \mathrm{~h}$ dietary records during the first 2 years of the study. The record days (two weekend days and four week days) were randomly assigned to volunteers and covered all seasons. These subjects had serum Se concentrations (1.13 (SD 0.20) $\mu \mathrm{mol} / 1, n 2717$ men; 1.09 (SD 0.18) $\mu \mathrm{mol} / 1, n 3673$ women) similar to those of the participants who did not agree to fill out dietary questionnaires (1.14 (SD 0.20) $\mu \mathrm{mol} / 1, n 2199$ men, $P=0.40$; 1.09 (SD 0.20) $\mu \mathrm{mol} / 1, n 3752$ women, $P=0.62$ ) during the first 2 years of the study. For the collection of dietary data, volunteers received a free small terminal specifically developed for the study and loaded with ad hoc software. This material enabled subjects to fill out computerized questionnaires off-line and to transmit data during a brief telephone connection via the Minitel Telematic Network, which connected them to the main SU.VI.M.AX computer server. The Minitel is a small terminal which was widely used at the beginning of the SU.VI.M.AX study in France as an adjunct to the telephone. Subjects were assisted in this task by the interactive facilities of the software, and by an instruction manual for coding foods, including photographs for estimations of portion size validated on 780 subjects in a pilot study (Le Moullec et al. 1996). Data were also collected on cooking methods, seasoning, type of foods (i.e. fresh, frozen, canned), and place and time of food intake. All dietary values reported here were based on the average intakes for six $24 \mathrm{~h}$ dietary records for each subject. For each selected food group, four categories $(<25$ th percentile, $25-<50$ th percentile, $50-<75$ th percentile, $\geq 75$ th percentile), were used for the analysis.

\section{Blood analysis}

At baseline, venous blood samples from subjects after a $12 \mathrm{~h}$ fast were collected in trace-element controlled Vacutainer ${ }^{\circledR}$ tubes (Becton Dickinson, Pont de Claix, France) in 12338 out of 13017 participants. Samples were delivered to Grenoble (University Hospital, Grenoble, France) in dry ice and kept frozen until analysed.

Se was determined in serum using electrothermal atomic absorption spectrometry (4100 ZL; Perkin Elmer, Norwalk, CT, USA) according to Arnaud et al. (1993). A Se electrodeless discharge lamp and a Zeeman longitudinal background correction were used. The matrix modifier used was Pt. A fivefolddiluted serum in a solution containing $0.1 \mathrm{M}$-nitric acid and $0.2 \%$ $(\mathrm{w} / \mathrm{v})$ Triton X-100 $(20 \mu \mathrm{l})$ and $30 \mu \mathrm{g}$ Pt was introduced on to the platform of a pyrolytic graphite furnace. Addition calibration was used and Seronorm ${ }^{\circledR}$ trace element serum was chosen as internal quality control (Sero ${ }^{\circledR}$, Billingstad, Norway). In addition, the laboratory has participated in two interlaboratory comparison trials organized by the French Society for Clinical Biology (SFBC, Nancy, France) and the Centre de toxicologie du Québec (Sainte-Foy, Québec, Canada) since 1988.

\section{Statistics}

Data were processed on an alpha-VMS system, and a specific database was developed using the Statistical Analysis System version 8.2 (SAS Inc., Cary, NC, USA). Serum Se concentrations were compared between men and women by Student's $t$ test. The $\chi^{2}$ test was used when appropriate. Serum Se values were expressed as means and standard deviations or as percentages. Further analyses 
were performed in men and women separately. The mean levels of serum Se were compared across categories of age, couple status, educational level, occupation status, geographic region, type of residence location, BMI, physical activity, smoking habits, alcohol and selected food consumption, and hormonal status, using the Fisher's test and/or by a test for a linear trend across categories. $P<0.05$ was considered as significant.

\section{Results}

Women had a lower mean level of serum Se than men: 1.09 $(\mathrm{SD} 0 \cdot 19) \mu \mathrm{mol} / 1(n$ 7423) for women and 1.14 (SD 0.20) $\mu \mathrm{mol} / \mathrm{l}$ ( $n$ 4915) for men $(P<0 \cdot 0001)$. All other analyses were therefore done separately in men and women. The percentages of serum Se values below $0.75 \mu \mathrm{mol} / 1$, considered to be a sub-deficient level by a European group of scientists (Van Dael \& Deelstra, 1993), were $1.3 \%$ in men and $1.7 \%$ in women. The percentages of serum Se values higher than $1.25 \mu \mathrm{mol} / \mathrm{l}$, which corresponds to optimal glutathione peroxidase activities (Nève, 2000; Rayman, 1997), were $25.3 \%$ in men and $17.4 \%$ in women. The unadjusted mean levels of serum Se by geographic region are presented separately in men (Fig. 1(A)) and women (Fig. 1(B)). The regional differences remained significant $(P<0.0001)$ after adjustment for age, smoking habits and education. The highest mean values were found in the North and in Normandy and the lowest in the Centre. With the exception of Brittany, the same geographic differences were observed in men and women. Table 1 presents the relationships between serum Se levels and socio-demographic data. The relationships between serum Se levels and couple status, educational level or occupational status altered with adjustment factors. In men, the type of resident area did not consistently influence serum $\mathrm{Se}$ levels although the global significance test was statistically significant. Serum Se concentrations increased with age in women $(P<0 \cdot 0001)$, but not in men, whatever the adjustment factors included (Fig. 2).

In addition, premenopausal women had serum Se concentrations lower than postmenopausal women (1.07 (SD 0.19) $\mu \mathrm{mol} / 1, \quad n \quad 5263 \quad v . \quad 1 \cdot 12 \quad$ (SD $0 \cdot 20) \quad \mu \mathrm{mol} / 1, \quad n \quad 2012$; $P<0.0001)$. This difference remained significant after controlling for age, smoking, education and region $(P<0.04)$ or when the analysis was performed in women aged $40-$ 55 years (unadjusted $P<0.0001$ and adjusted $P=0 \cdot 04$ ). In postmenopausal women, the use of hormonal supplement was not associated with a difference in Se serum concentrations (1.12 (SD 0.20) $\mu \mathrm{mol} / \mathrm{l}, n 1225$ v. 1.12 (SD 0.20) $\mu \mathrm{mol} / \mathrm{l}, \quad n 787, \quad P>0.86)$. However, in premenopausal women, those who used contraceptive-pills had higher serum Se concentrations (1.12 (SD 0.19) $\mu \mathrm{mol} / \mathrm{l}, n$ 908, $P<0.001)$ compared to those using an intrauterine device (1.06 (SD 0.18) $\mu \mathrm{mol} / \mathrm{l}, \quad n$ 1554), another contraceptive method (1.06 (SD 0.18$) \mu \mathrm{mol} / \mathrm{l}, n$ 617) or no contraceptive method (1.07 (SD 0.19) $\mu \mathrm{mol} / \mathrm{l}, n$ 2050). These differences remained significant after adjustment for age, smoking habits, education and regions.

As shown in Table 2, obese women (BMI $\geq 30 \mathrm{~kg} / \mathrm{m}^{2}$ ) had significantly lower serum Se concentrations than non-obese women. In both sexes, mean serum Se levels did not differ across physical activity groups. Smoking habits were inversely related to serum Se values, and a positive relationship was observed with alcohol intake. Red wine users had significantly higher serum Se concentration than other alcoholic drink users (1.14 (SD 0.20) $\mu \mathrm{mol} / 1, n 2396 v .1 \cdot 10$ (SD 0.19) $\mu \mathrm{mol} / 1, n$ 205, $P=0.009$, in men; 1.09 (SD 0.18) $\mu \mathrm{mol} / 1, n 2459 v .1 .08$ (SD 0.19) $\mu \mathrm{mol} / 1, n 731, P=0.03$, in women). This difference remained significant only in men after controlling for age, smoking, education, region and alcohol consumption $(P=0.03$ in men and $P=0.20$ in women). An increase in
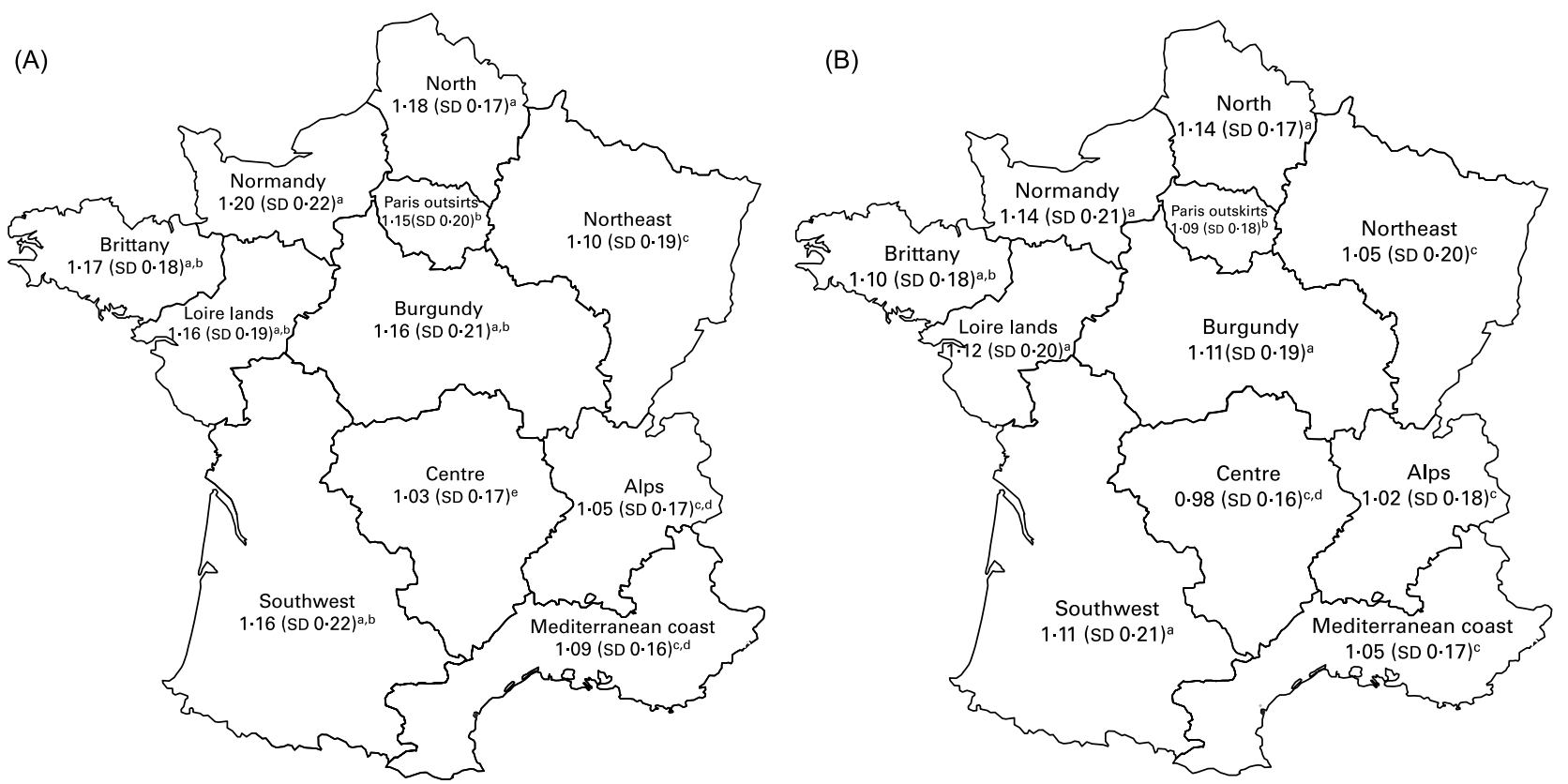

Fig. 1. French map of serum selenium concentrations $(\mu \mathrm{mol} / \mathrm{l})$ in men $(A)$ and women $(B)$. Values are means and standard deviations. ${ }^{a, b, c, d, e}$ Mean values with unlike superscript letters were significantly different $(P<0.05)$. Global adjusted or not $P<0.0001$; adjustment for age, smoking habits and education. 
Table 1. Relationship between occupation, environment, couple status and education, and unadjusted serum selenium concentrations $(\mu \mathrm{mol} / \mathrm{l})$ (Mean values and standard deviations)

\begin{tabular}{|c|c|c|c|c|c|c|}
\hline & \multicolumn{3}{|c|}{ Men } & \multicolumn{3}{|c|}{ Women } \\
\hline & Mean & SD & $n$ & Mean & SD & $n$ \\
\hline \multicolumn{7}{|l|}{ Couple status } \\
\hline No & $1 \cdot 12$ & 0.21 & 551 & 1.08 & 0.19 & 1577 \\
\hline Yes & $1 \cdot 14$ & 0.20 & 4244 & 1.09 & 0.19 & 5681 \\
\hline Unadjusted $P$ & 0.14 & & & 0.06 & & \\
\hline Adjusted $P^{\star}$ & 0.21 & & & 0.03 & & \\
\hline \multicolumn{7}{|l|}{ Education } \\
\hline Primary school & $1 \cdot 13$ & 0.22 & 1179 & $1 \cdot 10$ & 0.20 & 1413 \\
\hline High school & $1 \cdot 13$ & 0.20 & 1733 & 1.09 & 0.19 & 2900 \\
\hline University & $1 \cdot 14$ & 0.19 & 1944 & 1.08 & 0.19 & 3000 \\
\hline $\begin{array}{l}\text { Unadjusted } \\
P \text { for trend }\end{array}$ & $0 \cdot 13$ & & & 0.01 & & \\
\hline $\begin{array}{l}\text { Adjusted } \\
P \text { for trend } \dagger\end{array}$ & 0.21 & & & 0.49 & & \\
\hline \multicolumn{7}{|l|}{ Occupation } \\
\hline Employed & $1 \cdot 14$ & 0.19 & 3950 & $1.09^{a}$ & 0.19 & 5555 \\
\hline Unemployed & 1.14 & 0.22 & 333 & $1.08^{a}$ & 0.19 & 1451 \\
\hline Retired & $1 \cdot 13$ & 0.21 & 607 & $1 \cdot 11^{b}$ & $0 \cdot 21$ & 365 \\
\hline $\begin{array}{l}\text { Global } \\
\text { unadjusted } P\end{array}$ & 0.43 & & & 0.04 & & \\
\hline $\begin{array}{l}\text { Global } \\
\text { adjusted } P^{*}\end{array}$ & 0.63 & & & $0 \cdot 18$ & & \\
\hline \multicolumn{7}{|l|}{ Resident area } \\
\hline Urban & $1 \cdot 14^{c}$ & 0.20 & 3243 & 1.09 & 0.19 & 5049 \\
\hline Suburban & $1 \cdot 14^{c}$ & 0.19 & 716 & 1.08 & 0.20 & 1009 \\
\hline Mixed & $1 \cdot 10^{c}$ & 0.19 & 135 & 1.08 & 0.19 & 190 \\
\hline Rural & $1 \cdot 12^{c}$ & 0.19 & 811 & 1.09 & 0.19 & 1158 \\
\hline $\begin{array}{l}\text { Global } \\
\text { unadjusted } P\end{array}$ & 0.02 & & & 0.87 & & \\
\hline $\begin{array}{l}\text { Global } \\
\text { adjusted } P \ddagger\end{array}$ & 0.04 & & & 0.92 & & \\
\hline
\end{tabular}

* Adjustment for age, smoking habits, education and region.

$\dagger$ Adjustment for age, smoking habits and region.

$\ddagger$ Adjustment for age, smoking habits and education.

a,b,c Means within the levels of variables with unlike superscript letters were significantly different $(P<0.05)$

meat and fish consumption was also associated with higher serum Se concentrations (Table 3), whereas lower levels of serum $\mathrm{Se}$ were observed in male heavy consumers of vegetables and fruits (Table 3).

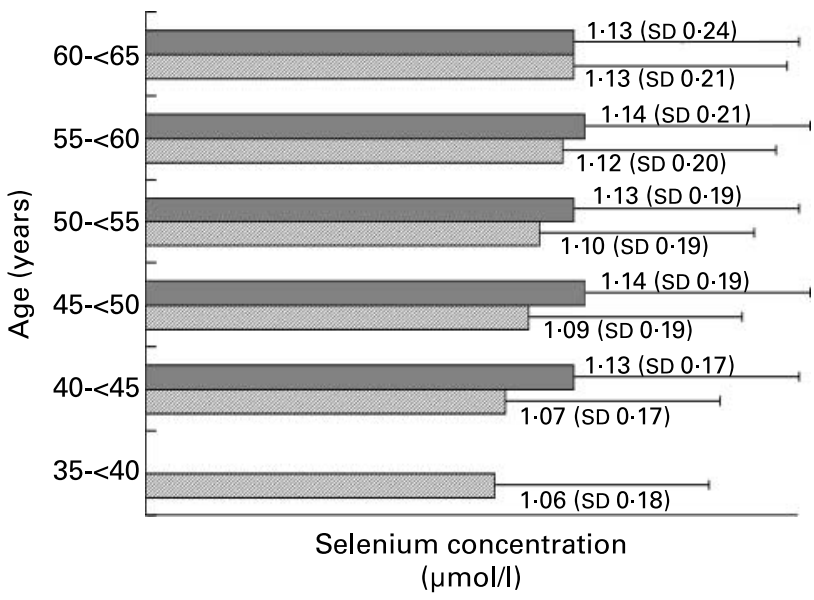

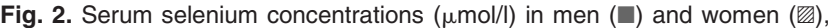
depending on age. Values are means and standard deviations. Adjusted or not $P$ for trend $<0.0001$ for women and $>0.89$ for men; adjustment for smoking habits, education and region.

\section{Discussion}

Epidemiological studies have suggested that low Se status is associated with an increased risk of a number of diseases, including cancer, thyroid and neurological impairment, infectious diseases and CVD (Berr, 2000; Combs, 2001; Rayman, 2002; Patrick, 2004). Thus, the assessment of Se status determinants is useful. Previous investigations on serum Se determinants yielded conflicting results, probably due to differences in the number of subjects, the geographic region and selection criteria (Robberecht \& Deelstra, 1994; Alfthan \& Nève, 1996). Some of the significant associations found in the present work were probably revealed because of the large sample size.

Compared to previous studies conducted in French adults, serum Se concentrations in the present study were slightly higher or else were similar (Thorling et al. 1986; Simonoff et al. 1988; Dubois et al. 1990; Arnaud \& Preziosi, 1994). Only a very limited number of our participants had serum Se values lower than $0.75 \mu \mathrm{mol} / \mathrm{l}$, the level considered to reflect inadequate Se status (Nève, 1991; Van Dael \& Deelstra, 1993). However, $82.6 \%$ of women and $74.8 \%$ of men had a serum Se concentration below $1.25 \mu \mathrm{mol} / \mathrm{l}$, the cut-off considered to be required for optimal glutathione peroxidase activity (Rayman, 1997; Nève, 2000) which confirmed that French Se intakes (Lamand et al. 1994) are lower than those necessary for optimal health (Nève, 2000; Broome et al. 2004; Thomson, 2004). Nevertheless, the present results contrast with the dramatic decrease in serum Se concentrations observed in the UK (Rayman, 1997) as a consequence of the drop in the importing of wheat from North America. Our results may be related to the non-random selection of volunteers. Although baseline characteristics of the SU.VI.M.AX participants were found to be close to the national population with regard to geographic density and socio-economic status (Hercberg et al. 1998), participants in the SU.VI.M.AX study may have been more aware of their nutrition than the overall French population.

The sex differences found in the present study had been previously reported in other studies (Kafai \& Ganji, 2003; Niskar et al. 2003; Pavao et al. 2003), despite remaining controversial (Robberecht \& Deelstra, 1994; Alfthan \& Nève, 1996; Hansen et al. 2004). In particular, a previous study performed in French adults using similar selection criteria failed to find sex differences in serum Se concentrations (Arnaud \& Preziosi, 1994). The sex difference has been attributed to differences in body weight, hormonal status and food habits (Alfthan \& Nève, 1996). However, our results showed that serum Se concentrations in men were not associated with BMI, in agreement with previous studies (Telisman et al. 2001; Koyama et al. 1995), and serum Se concentrations were lower in obese women than in non-obese women, possibly because of the increased oxidative stress reported in overweight and obese people (Fenster et al. 2002; Keaney et al. 2003) or because of different eating habits. Therefore, BMI may not explain the difference between men and women in the present study. More interestingly, the increase in serum concentrations with an increase in fish, meat and alcohol consumption may contribute to the difference between genders (Alfthan \& Nève, 1996), since consumption of these foods and beverages was higher in men than in women. 
Table 2. Adjusted serum selenium concentrations $(\mu \mathrm{mol} / \mathrm{l})$ according to anthropometric and lifestyle characteristics (Mean values and standard deviations)

\begin{tabular}{|c|c|c|c|c|c|c|}
\hline & \multicolumn{3}{|c|}{ Men } & \multicolumn{3}{|c|}{ Women } \\
\hline & Mean & SD & $n$ & Mean & SD & $n$ \\
\hline \multicolumn{7}{|l|}{ BMI $\left(\mathrm{kg} / \mathrm{m}^{2}\right)$} \\
\hline$<25$ & $1 \cdot 13$ & 0.19 & 2335 & 1.09 & 0.22 & 5540 \\
\hline $25-<30$ & $1 \cdot 14$ & 0.18 & 2000 & 1.09 & 0.20 & 1084 \\
\hline$\geq 30$ & $1 \cdot 14$ & 0.20 & 276 & 1.06 & 0.20 & 323 \\
\hline Adjusted $P$ for trend ${ }^{*}$ & 0.88 & & & 0.01 & & \\
\hline \multicolumn{7}{|l|}{ Physical activity } \\
\hline Irregular & $1 \cdot 13$ & 0.20 & 1100 & 1.09 & 0.17 & 1875 \\
\hline$<1 \mathrm{~h} / \mathrm{d}$ & $1 \cdot 14$ & 0.21 & 1212 & 1.08 & 0.20 & 2481 \\
\hline$\geq 1 \mathrm{~h} / \mathrm{d}$ & $1 \cdot 14$ & 0.20 & 2407 & 1.09 & 0.21 & 2742 \\
\hline Adjusted $P$ for trend ${ }^{*}$ & 0.32 & & & 0.26 & & \\
\hline \multicolumn{7}{|l|}{ Smoking habits } \\
\hline Never smokers & $1 \cdot 14$ & 0.16 & 1616 & 1.09 & 0.19 & 3904 \\
\hline Former smokers & $1 \cdot 14$ & 0.24 & 2385 & 1.09 & 0.18 & 2067 \\
\hline Light smokers $(<10$ cigarettes $/ d)$ & $1 \cdot 14$ & 0.20 & 332 & 1.07 & 0.20 & 602 \\
\hline Moderate smokers $(10-20$ cigarettes/d) & 1.09 & 0.19 & 262 & 1.07 & 0.18 & 401 \\
\hline Heavy smokers $(>20$ cigarettes/d) & 1.08 & $0 \cdot 20$ & 142 & 1.05 & 0.19 & 159 \\
\hline Adjusted $P$ for trend $\dagger$ & $<0.0001$ & & & 0.002 & & \\
\hline \multicolumn{7}{|l|}{ Alcohol intake $(\mathrm{g} / \mathrm{d})$} \\
\hline 0 & $1 \cdot 11$ & 0.21 & 875 & 1.07 & 0.16 & 2909 \\
\hline$<15$ (women) or 20 (men) & $1 \cdot 14$ & 0.20 & 520 & 1.09 & 0.19 & 2185 \\
\hline$\geq 15$ (women) or 20 (men) & $1 \cdot 14$ & 0.22 & 3087 & $1 \cdot 11$ & 0.19 & 1525 \\
\hline Adjusted $P$ for trend ${ }^{*}$ & $<0.0001$ & & & $<0.0001$ & & \\
\hline
\end{tabular}

${ }^{*}$ Adjustment for age, smoking habits, education and region. † Adjustment for age, education and region.

Hormonal status may partly explain the differences observed between sex and age. Indeed, postmenopausal women exhibited higher serum Se concentrations than premenopausal women after adjustment for age, in contrast to the results of Bergmann et al. (1998). However, as previously reported in Belgium (Verlinden et al. 1983), women taking oral contraceptives exhibited higher serum Se concentrations than other premenopausal groups. This observation is in agreement with the strong positive relationship between plasma oestrogen and plasma Se concentrations reported by Smith et al. (2000) in the USA. However, postmenopausal women, whether using hormonal replacement therapy or not, had similar serum Se concentrations, in agreement with previous results (Bureau et al. 2002). Therefore, the role of sex hormones in explaining differences between genders, and the regular increase in serum Se concentrations with increasing age in women, as reported previously (Kafai \& Ganji, 2003; Pavao et al. 2003), remains to be elucidated (Robberecht \& Deelstra, 1994). In men, serum Se concentrations were not related to age, in agreement with previous studies conducted in adults (Dubois et al. 1990; Robberecht \& Deelstra, 1994; Telisman et al. 2001; Kafai \& Ganji, 2003; Niskar et al. 2003; Pavao et al. 2003). The present results confirm that the decrease in serum Se concentrations with age is observed only in the elderly (Dubois et al. 1990; Robberecht \& Deelstra, 1994; Kafai \& Ganji, 2003).

Variations in serum Se concentrations according to geographic region are well known (Nève, 1991; Robberecht \& Deelstra, 1994; Alfthan \& Nève, 1996; Rayman, 1997; Golubkina \& Alfthan, 1999; Niskar et al. 2003) and are related to Se intake. However, the present results contrast with reported French Se intakes (Simonoff \& Simonoff,
1991). In the present study, serum Se concentrations were highest in the North and lowest in the Centre. Se intake according to the study of Simonoff \& Simonoff (1991) was highest in the Southwest and the East, and lowest in Paris. The observed differences may be related to study design. Simonoff \& Simonoff (1991) measured Se concentration in 200 foods and have calculated daily Se intake using Institut National de la Statistique et des Etudes Economiques food consumption tables. Men living in a rural community tended to exhibit lower Se values than those in an urban community, as previously reported in other studies (Snook et al. 1983; Backovic et al. 1999), but this remains controversial (Niskar et al. 2003). As in the NHANES III survey (Niskar et al.), serum Se concentrations were not related to urban status in women. Interestingly, in the present study the mountain regions (Centre, Alps) seemed more at risk of low serum Se concentrations than other regions. The hypothesis that consumption of fish, a good Se food source, is higher near the sea was not supported by SU.VI.M.AX results.

The influence of education and couple status on serum Se concentrations has not been extensively studied. Our present results show no evidence of a major impact of these factors, but this is not in agreement with previous studies which reported an increase in serum Se with increased education (Berr et al. 1998; Kilander et al. 2001). On the contrary, in women, the unadjusted serum $\mathrm{Se}$ values significantly decreased with an increase in education. The increase in serum Se in women who lived in couple, after adjustment, can be explained at least partly by an increase in meat consumption but not by differences in seafood or alcohol consumption (SU.VI.M.AX data). 
Table 3. Median (25th and 75th quartiles) consumption of foods ( $\mathrm{g} / \mathrm{d}$ ) during the first 2 years of SU.VI.M.AX (Supplémentation en Vitamines et Minéraux Antioxydants) and adjusted mean baseline serum selenium concentrations ( $\mu \mathrm{mol} / \mathrm{l})$ according to food consumption

(Mean values and standard deviations)

\begin{tabular}{|c|c|c|c|c|c|c|}
\hline & \multicolumn{3}{|c|}{ Men } & \multicolumn{3}{|c|}{ Women } \\
\hline & Mean (range) & SD & $n$ & Mean (range) & SD & $n$ \\
\hline Dairy products consumption (g/d) & $237(135-353)$ & & & $229(139-345)$ & & \\
\hline$<25$ th percentile & 1.14 & 0.21 & 662 & 1.09 & 0.18 & 892 \\
\hline $25-<50$ th percentiles & $1 \cdot 13$ & 0.20 & 656 & 1.09 & $0 \cdot 18$ & 884 \\
\hline $50-<75$ th percentiles & $1 \cdot 12$ & 0.21 & 662 & 1.08 & 0.18 & 892 \\
\hline$\geq 75$ th percentile & $1 \cdot 14$ & 0.21 & 661 & 1.09 & $0 \cdot 18$ & 898 \\
\hline Adjusted $P$ for trend* & 0.56 & & & 0.34 & & \\
\hline Meat consumption (g/d) & $91(63-125)$ & & & $63(42-88)$ & & \\
\hline$<25$ th percentile & $1 \cdot 10$ & $0 \cdot 20$ & 654 & 1.07 & 0.18 & 884 \\
\hline $25-<50$ th percentiles & $1 \cdot 13$ & $0 \cdot 20$ & 658 & 1.08 & 0.18 & 897 \\
\hline $50-<75$ th percentiles & $1 \cdot 14$ & 0.21 & 663 & $1 \cdot 10$ & 0.18 & 891 \\
\hline$\geq 75$ th percentile & $1 \cdot 16$ & $0 \cdot 21$ & 666 & $1 \cdot 10$ & 0.18 & 894 \\
\hline Adjusted $P$ for trend ${ }^{\star}$ & $<0.0001$ & & & 0.0001 & & \\
\hline Fish and seafoods consumption (g/d) & $40(21-64)$ & & & $32(16-51)$ & & \\
\hline 25th percentile & 1.08 & $0 \cdot 20$ & 659 & 1.05 & 0.18 & 891 \\
\hline $25-<50$ th percentiles & $1 \cdot 12$ & 0.20 & 656 & 1.08 & 0.18 & 883 \\
\hline $50-<75$ th percentiles & $1 \cdot 15$ & 0.21 & 665 & 1.09 & 0.18 & 908 \\
\hline$\geq 75$ th percentile & $1 \cdot 18$ & 0.21 & 661 & $1 \cdot 12$ & 0.18 & 884 \\
\hline Adjusted $P$ for trend ${ }^{*}$ & $<0.0001$ & & & $<0.0001$ & & \\
\hline Fruits and vegetables consumption $(\mathrm{g} / \mathrm{d})$ & $291(196-404)$ & & & $274(195-373)$ & & \\
\hline 25th percentile & 1.14 & 0.21 & 661 & 1.08 & 0.18 & 887 \\
\hline $25-<50$ th percentiles & $1 \cdot 14$ & 0.21 & 662 & 1.08 & 0.18 & 888 \\
\hline $50-<75$ th percentiles & $1 \cdot 13$ & 0.20 & 658 & 1.09 & 0.18 & 891 \\
\hline$\geq 75$ th percentile & 1.12 & 0.21 & 660 & 1.09 & 0.18 & 900 \\
\hline Adjusted $P$ for trend ${ }^{*}$ & 0.01 & & & 0.39 & & \\
\hline Starchy foods consumption (g/d) & $55(31-90)$ & & & $40(20-65)$ & & \\
\hline$<25$ th percentile & 1.13 & $0 \cdot 20$ & 643 & 1.09 & 0.18 & 885 \\
\hline $25-<50$ th percentiles & $1 \cdot 14$ & 0.21 & 673 & 1.09 & $0 \cdot 18$ & 891 \\
\hline $50-<75$ th percentiles & $1 \cdot 13$ & 0.20 & 657 & 1.08 & 0.18 & 889 \\
\hline$\geq 75$ th percentile & $1 \cdot 13$ & 0.21 & 668 & 1.08 & 0.18 & 901 \\
\hline Adjusted $P$ for trend* & 0.80 & & & 0.12 & & \\
\hline Bread and cereals consumption (g/d) & $136(94-186)$ & & & $87(60-121)$ & & \\
\hline 25th percentile & 1.14 & 0.20 & 653 & 1.09 & 0.18 & 891 \\
\hline $25-<50$ th percentiles & $1 \cdot 13$ & 0.20 & 658 & 1.08 & 0.18 & 888 \\
\hline $50-<75$ th percentiles & $1 \cdot 15$ & 0.21 & 661 & 1.09 & 0.18 & 889 \\
\hline$\geq 75$ th percentile & $1 \cdot 11$ & 0.21 & 669 & 1.09 & 0.18 & 898 \\
\hline Adjusted $P$ for trend ${ }^{*}$ & 0.12 & & & 0.73 & & \\
\hline Fats consumption (g/d) & $23(16-33)$ & & & $20(14-28)$ & & \\
\hline$<25$ th percentile & 1.14 & 0.20 & 654 & 1.08 & 0.18 & 885 \\
\hline $25-<50$ th percentiles & $1 \cdot 14$ & 0.20 & 658 & 1.09 & 0.18 & 887 \\
\hline $50-<75$ th percentiles & $1 \cdot 13$ & $0 \cdot 21$ & 663 & 1.08 & 0.18 & 895 \\
\hline$\geq 75$ th percentile & $1 \cdot 13$ & 0.21 & 666 & 1.08 & 0.18 & 899 \\
\hline Adjusted $P$ for trend ${ }^{*}$ & 0.27 & & & 0.61 & & \\
\hline
\end{tabular}

${ }^{*}$ Adjustment for age, education, smoking habits, region and energy intake.

Serum Se concentrations were not related to physical activity, in agreement with previous studies (Tessier et al. 1995; Pincemail et al. 2000).

The effect of smoking is controversial (Robberecht \& Deelstra, 1994; Alfthan \& Nève, 1996). In the present study, the decrease in serum Se concentrations was observed in smokers, in agreement with some (Hughes et al. 1998; Telisman et al. 2001; Kafai \& Ganji, 2003; Niskar et al. 2003; Hansen et al. 2004; Thomson, 2004) but not all (Verlinden et al. 1983; Koyama et al. 1995; Borawska et al. 2004) previous studies. It has been reported that the decrease in serum Se concentrations in smokers might be related to oxidative stress (Hansen et al. 2004; Thomson, 2004) or to low dietary intake (Kafai \& Ganji, 2003).
The increase in serum Se with a moderate increase in alcohol consumption contrasts with the decrease in serum Se concentrations reported in alcohol abusers (Robberecht \& Deelstra, 1994), but a similar trend was observed in the NHANES III women (Kafai \& Ganji, 2003) and suggests that moderate alcohol consumption may not adversely affect serum Se concentrations in subjects with adequate Se status (Borawska et al. 2004). Indeed, the decrease in Se concentrations observed in alcohol abusers has been reported to be associated with the deterioration of liver function, undernutrition (Robberecht \& Deelstra, 1994; Alfthan \& Nève, 1996) or moderate Se deficiency (Borawska et al. 2004), which is not the case in our population. Indeed, only $1.24 \%$ men and $0.16 \%$ women consumed more than $80 \mathrm{~g}$ alcohol daily, 
$0.5 \%$ men and $4.4 \%$ women were undernourished $(\mathrm{BMI}<18.5)$ and less than $2 \%$ had a serum Se concentration lower than $0.75 \mu \mathrm{mol} / \mathrm{l}$. Moreover, some previous work failed to demonstrate a relationship between alcoholic beverage consumption and serum Se concentrations in middle-aged men (Koyama et al. 1995; Kafai \& Ganji, 2003). Finally, we suggest that the increase in serum Se concentration in red wine users reflects a protective effect against oxidative stress which is counteracted in women by confounding factors.

Among the selected food groups, consumption of meat and seafood during the first 2 years of SU.VI.M.AX was strongly related to baseline serum Se concentrations. The present results are in agreement with previous studies conducted in Europe (Thorngren \& Akesson, 1987; Luoma, 1998; Bergmann et al. 1998; Hagmar et al. 1998; Pavao et al. 2003; Hansen et al. 2004) and may be related both to the high Se concentrations in these foods (Zhang et al. 1993; Lamand et al. 1994, 1996; Hansen et al. 2004) and to good Se absorption and retention (Shi \& Spallholz, 1994; Bugel et al. 2001, 2004; Finley et al. 2004) of such foods. Interestingly, Thorngren \& Akesson (1987) demonstrated that an increase in fish consumption significantly increased the serum Se concentration within 3 weeks. However, this relationship was not found in Canadian fishermen (Kosatsky et al. 2000). In Norway, Meltzer et al. (1993) reported low Se bioavailability from fish, possibly due to heavy metal interactions and the nature of Se species. In contrast to seafood and meat, fruits, vegetables, starchy foods and milk contain little Se (Zhang et al. 1993; Lamand et al. 1994, 1996). Moreover, Se bioavailability from broccoli is reported to be low in rats (Finley et al. 2004). These low Se concentrations may explain the weak relationship between the consumption of these foods during the first 2 years of SU.VI.M.AX and baseline serum Se concentrations observed in the present study. The negative linear relationship between serum Se concentrations and consumption of fruits and vegetables, observed only in men, may be the consequence of a decrease in adequate Se food sources. The lack of a positive linear relationship between serum Se concentrations and the consumption of bread and cereals contrasts with previous data (Meltzer et al. 1992, 1993; Borawska et al. 2004). However, the positive link between serum Se concentrations and wheat consumption is more likely related to Se content, and therefore to geographic origin or to Se enrichment, than to the wheat itself (Meltzer et al. 1993; Golubkina \& Altfhan, 1999; Djujic et al. 2000). In France, wheat is not a good source of Se and the concentrations of Se in bread and cereals are low (Lamand et al. 1994, 1996).

In conclusion, our data provide information from the first large-scale study conducted in French adults close to the French age-match population. Se status of most SU.VI.M.AX participants is not adequate for optimum selenoproteins and immune functions, and for cognitive and cancer protection (Berr, 2000; Broome et al. 2004; Thomson, 2004), even if the rate of biological sub-deficiency is low. We reported differences between men and women. Factors such as meat and fish consumption, smoking, moderate alcohol intake and geographic area were the main identified determinants. With respect to the key role of adequate Se status in prevention of diseases such as cancer, CVD and cognitive decline, other European large-scale intervention studies must be performed in a general population in order to determine the importance of Se status.

\section{Acknowledgements}

We are grateful to the staff of the SU.VI.M.AX study, to all those who helped in carrying out the study, and to the dedicated and conscientious volunteers who participated in this trial.

\section{References}

Alfthan G \& Nève J (1996) Reference values for serum selenium in various areas evaluated according to the TRACY protocol. J Trace Elem Med Biol 10, 77-87.

Arnaud J \& Preziosi P (1994) Réponse du zinc et du sélénium sériques au supplément vitaminique et minéral antioxydant chez des volontaires sains. L'Eurobiologiste 28, 161-165.

Arnaud J, Prual A, Preziosi P, Favier A \& Hercberg S (1993) Selenium determination in human milk in Niger: influence of maternal status. J Trace Elem Electrolytes Health Dis 7, 199-204.

Backovic D, Marinkovic J, Jorga J, Pavlica M, Maksimovic Z \& Nikolic M (1999) Environmental factors, health-related habits, and serum selenium levels in cancer patients and healthy controls. Biol Trace Elem Res 67, 55-62.

Bergmann S, Neumeister V, Siekmeier R, Mix C, Wahrburg U \& Jaross W (1998) Food supply abundant increase of serum selenium concentrations in middle-aged Dresden women between 19901996. DRECAN-team. Dresden cardiovascular risk and nutrition. Toxicol Lett 96/97, 181-187.

Berr C (2000) Cognitive impairment and oxidative stress in the elderly: results of epidemiological studies. Biofactors 13, 205-209.

Berr C, Coudray C, Bonithon-Kopp C, Roussel AM, Mainard F \& Alperovitch A (1998) Demographic and cardiovascular risk factors in relation to antioxidant status; the EVA study. Int J Vitam Nutr Res 68, 26-35.

Borawska MH, Witkowska AM, Hukalowicz K \& Markiewicz R (2004) Influence of dietary habits on serum selenium concentration. Ann Nutr Metab 48, 134-140.

Bradley KA, Badrinath S, Bush K, Boyd-Wickizer J \& Anawalt B (1998) Medical risks for women who drink alcohol. J Gen Intern Med 13, 627-639.

Broome CS, McArdle F, Kyle JAM, Andrews F, Lowe NM, Hart CA, Arthur JR \& Jackson MJ (2004) An increase in selenium intake improves immune function and poliovirus handling in adults with marginal selenium status. Am J Clin Nutr 80, 154-162.

Bugel SH, Sandstrom B \& Larsen EH (2001) Absorption and retention of selenium from shrimps in man. J Trace Elem Med Biol 14, 198-204.

Bugel S, Sandstrom B \& Skibsted LH (2004) Pork meat: a good source of selenium?" J Trace Elem Med Biol 17, 307-311.

Bureau I, Anderson R, Arnaud J, Raysiguier Y, Favier A \& Roussel AM (2002) Trace mineral status in post menopausal women: impact of hormonal replacement therapy. J Trace Elem Med Biol 16, 9-13.

Combs GF (2001) Selenium in global food systems. Br J Nutr 85 517-547.

de Lorimier AA (2000) Alcohol, wine, and health. Am J Surg 180, $357-361$.

Djujic IS, Jozanov-Stankov ON, Milovac M, Jankovic V \& Djermanovic V (2000) Bioavailability and possible benefits of wheat intake naturally enriched with selenium and its products. Biol Trace Elem Res 77, 273-285.

Dubois F, Teby A, Belleville F, Nabet P \& Paysant P (1990) Valeurs usuelles du sélénium sérique dans une population de l'est de la France (Common values of serum selenium in a population in Eastern France). Ann Biol Clin 48, 28-32.

Fenster CP, Weinsier RL, Darley-Usmar VM \& Patel RP (2002) Obesity, aerobic exercise, and vascular disease: the role of oxidant stress. Obes Res 10, 964-968.

Finley JW, Grusak MA, Keck AS \& Gregoire BR (2004) Bioavailability of selenium from meat and broccoli as determined by retention and distribution of ${ }^{75}$ Se. Biol Trace Elem Res 99, 191-209. 
Golubkina NA \& Alfthan GV (1999) The human selenium status in 27 regions of Russia. J Trace Elem Med Biol 13, 15-20.

Hagmar L, Persson-Moschos M, Akesson B \& Schutz A (1998) Plasma levels of selenium, selenoprotein $\mathrm{P}$ and glutathione peroxidase and their correlations to fish intake and serum levels of thyrotropin and thyroid hormones: a study on Latvian fish consumers. Eur J Clin Nutr 52, 796-800.

Hansen JC, Deutch B \& Pedersen HS (2004) Selenium status in Greenland Inuit. Sci Tot Environ 331, 207-214.

Hercberg S, Galan P, Preziosi P, Bertrais S, Mennen L, Malvy D, Roussel AM, Favier A \& Briancon S (2004) The SU.VI.M.AX study: a randomized, placebo-controlled trial of the health effects of antioxidant vitamins and minerals. Arch Intern Med 164, $2335-2342$.

Hercberg S, Preziosi P, Briançon S, Galan P, Paul-Dauphin A, Malvy D, Roussel AM \& Favier A (1998) A primary prevention trial using nutritional doses of antioxidant vitamins and minerals in cardiovascular diseases and cancers in a general population: the SU.VI.M.AX study design, methods, and participant characteristics. SUpplementation en VItamines et Mineraux AntioXydants. Control Clin Trials 19, 336-351.

Hines LM \& Rimm EB (2001) Moderate alcohol consumption and coronary heart disease: a review. Postgrad Med J 77, 747-752.

Hughes K, Choo M, Kuperan P, Ong CN \& Aw TC (1998) Cardiovascular risk factors in relation to cigarette smoking: a population-based survey among Asians in Singapore. Atherosclerosis 137, 253-258.

Kafai MR \& Ganji V (2003) Sex, age, geographical location, smoking, and alcohol consumption influence serum selenium concentrations in the USA: third national health and nutrition examination survey, 1988-1994. J Trace Elem Med Biol 17, 13-18.

Keaney JF, Larson MG, Vasan RS, Wilson PWF, Lipinska I, Corey D, Massaro JM, Sutherland P, Vita JA \& Benjamin EJ (2003) Obesity and systemic oxidative stress. Clinical correlates of oxidative stress in the Framingham study. Arterioscler Thromb Vasc Biol 23, 434-439.

Kilander L, Berglund L, Boberg M, Vessby B \& Lithell H (2001) Education, lifestyle factors and mortality from cardiovascular disease and cancer. A 25-year follow-up of Swedish 50-year-old men. Int J Epidemiol 30, 1119-1126.

Kosatsky T, Przybysz R \& Armstrong B (2000) Mercury exposure in Montrealers who eat St Lawrence river sportfish. Environ Res 84, $36-43$.

Koyama H, Watanabe C, Satoh H, Hosokai H \& Tamura S (1995) Consistent relationship between selenium and apolipoprotein A-II concentrations in the sera of fasting middle-aged male abstainers and regular consumers of alcohol. Biol Trace Elem Res 50, $33-42$.

Lamand M, Tressol JC \& Bellanger J (1994) The mineral and trace element composition in French food items and intake levels in France. J Trace Elem Electrolytes Health Dis 8, 195-202.

Lamand M, Tressol JC, Ireland-Ripert J, Favier JC \& Feinberg M (1996) Répertoire général des aliments. Paris: Technique et Documentation, INRA.

Le Jeannic T \& Vidalenc J (1997) Pôles urbains et périurbanisation - Le zonage en aires urbaines. Paris: INSEE Première 516.

Le Moullec N, Deheeger M, Preziosi P, Montero P, Valeix P, RollandCachera MF, Potier de Courcy G, Christides JP, Galan P \& Hercberg S (1996) Validation du manuel-photos utilisé pour l'enquête alimentaire de l'étude SU.VI.M.AX. Cah Nutr Diet 31, 158-164.

Luoma P (1998) Antioxidants, infections and environmental factors in health and disease in northern Finland. Int J Circumpolar Health 57, 109-113.

Meltzer HM, Bibow K, Paulsen IT, Mundal HH, Norheim G \& Holm H (1993) Different bioavailability in humans of wheat and fish selenium as measured by blood platelet response to increased dietary Se. Biol Trace Elem Res 36, 229-241.
Meltzer HM, Norheim G, Loken EB \& Holm H (1992) Supplementation with wheat selenium induces a dose-dependent response in serum and urine of a Se-replete population. Br J Nutr 67, 287-294.

Nève J (1991) Methods in determination of selenium states. $J$ Trace Elem Electrolytes Health Dis 5, 1-17.

Nève J (2000) New approaches to assess selenium status and requirement. Nutr Rev 58, 363-369.

Niskar AS, Paschal DC, Kieszak SM, Flegal KM, Bowman B, Gunter EW, Pirkle JL, Rubin C, Sampson EJ \& McGeehin M (2003) Serum selenium levels in the US population. Biol Trace Elem Res 91, 1-10.

Patrick L (2004) Selenium biochemistry and cancer: a review of the literature. Altern Med Rev 9, 239-258.

Pavao ML, Cordeiro C, Costa A, Raposo JA, Santos MC, Nève J \& Viegas-Crespo AM (2003) Comparison of whole blood glutathione peroxidase activity, levels of serum selenium, and lipid peroxidation in subjects from the fishing and rural communities of 'Rabo de Peixe' village, San Miguel island, The Azores archipelago, Portugal. Biol Trace Elem Res 92, 27-40.

Pincemail J, Lecomte J, Castiau JP, Collard E, Vasankari T, Cheramy-Bien JP, Limet R \& Defraigne JO (2000) Evaluation of autoantibodies against oxidized LDL and antioxidant status in top soccer and basketball players after 4 months of competition. Free Rad Biol Med 28, 559-565.

Rayman MP (1997) Dietary selenium: time to act. $\mathrm{Br}$ Med J 314, $387-388$.

Rayman MP (2002) The argument for increasing selenium intake. Proc Nutr Soc 61, 203-215.

Robberecht H \& Deelstra H (1994) Factors influencing blood selenium concentration values: a literature review. J Trace Elem Electrolytes Health Dis 8, 129-143.

Shi B \& Spallholz JE (1994) Selenium from beef is highly bioavailable as assessed by liver glutathione peroxidase (EC 1.11.1.9) activity and tissue selenium. Br J Nutr 72, 873-881.

Simonoff M, Conri C, Fleury B, Berdeu B, Moretto P, Ducloux G \& Llabador Y (1988) Serum and erythrocyte selenium in normal and pathological states in France. Trace Elem Med 5, 64-69.

Simonoff M \& Simonoff G (1991) Le sélénium et la vie. Paris: Masson.

Smith AM, Chang MPH \& Medeiros LC (2000) Generational differences in selenium status of women. Biol Trace Elem Res 75, $157-165$.

Snook JT, Palmquist DL, Moxon AL, Cantor AH \& Vivian VM (1983) Selenium status of a rural (predominantly Amish) community living in a low-selenium area. Am J Clin Nutr 38, 620-630.

Telisman S, Jurasovic J, Pizent A \& Cvitkovic P (2001) Blood pressure in relation to biomarkers of lead, cadmium, copper, zinc, and selenium in men without occupational exposure to metals. Environ Res 87, 57-68.

Tessier F, Margaritis I, Richard MJ, Moynot C \& Marconnet P (1995) Selenium and training effects on the glutathione system and aerobic performance. Med Sci Sports Exerc 27, 390-396.

Thomson CD (2004) Assessment of requirements for selenium and adequacy of selenium status: a review. Eur J Clin Nutr 58, 391-402.

Thorling EB, Overvad K \& Geboers J (1986) Selenium status in Europe - human data. A multicenter study. Ann Clin Res 18, 3-7.

Thorngren M \& Akesson B (1987) Effect of dietary fish on plasma selenium and its relation to haemostatic changes in healthy adults. Int J Vit Nutr Res 57, 429-435.

Van Dael P \& Deelstra H (1993) Selenium. Int J Vit Nutr Res 63, 312-316.

Verlinden M, Van Sprundel M, Van der Auwera JC \& Eylenbosch WJ (1983) The selenium status of Belgian population groups. 1. Healthy adults. Biol Trace Elem Res 5, 91-102.

Zhang X, Shi B \& Spallholz JE (1993) The selenium content of selected meats, seafoods, and vegetables form Lubbock, Texas. Biol Trace Elem Res 39, 161-169. 